\title{
Voiko kone kieltäytyä töistä?
}

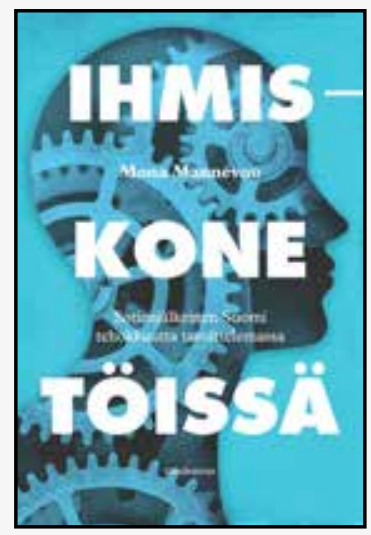

Mona Mannevuo: Ihmiskone töissä. Sotienjälkeinen Suomi tehokkuutta tavoittelemassa. Helsinki, Gaudeamus 2020.

Miten ihmisistä kasvatetaan tuottavampia työntekijöitä, jotka sopeutuvat yrityksen ja kansakunnan suurempien tavoitteiden suorittajiksi?

Mona Mannevuon tutkimusten mukaan sekä yhdysvaltalaisessa että suomalaisessa tehokkuusajattelussa on reilun sadan vuoden ajan etsitty tähän kysymykseen vastausta kahdesta eri suunnasta, jotka saattavat aluksi tuntua vastakkaisilta. Ensinnäkin työn järjestämisen uudistajat Henry Fordista ja Frederick W. Taylorista Googlen johtajiin ovat pitäneet tärkeänä hallita työntekijöiden haluja ja affekteja. Toiseksi työn tehostajat ovat tarkastelleet ihmistä koneena, jota pitää korjata, huoltaa ja optimoida, jotta siihen syötetystä energiavirrasta saisi mahdollisimman hyvän työpanoksen.

Tavoitteena on siis ollut järkiperäisesti tehostettu ihmiskone, jonka tunteita pyritään säätelemään olosuhteiden mukaan. Kyse ei ole suoraviivaisesta alistamisesta, koska tällaiseen työn rationalisointiin kuuluu hyvää tarkoittavia näkemyksiä, joiden mukaan toimenpiteet ovat tieteellisesti perusteltuja ja parantavat myös työntekijöiden asemaa.
Mannevuo esitti väitöskirjassaan Affektitehdas (2015), että työläisten affektit ovat 1900-luvun alusta asti olleet työn tehostamisen ytimessä. Esimerkiksi Ford rakensi tehtaansa tunteiden ympärille, tosin siten, että tunteet eivät saaneet häiritä tuotantoprosessia. Nykyisissä länsimaisissa työn järjestämisen tavoissa innostuneisuus, sosiaalisuus ja itsekorostus ovat puolestaan hyveitä, joiden ajatellaan parantavan tuotantoa. Sekä fordistisessa että postfordistisessa työn tehostamisessa on kuitenkin kyse "työläisten tietämisestä" eli työntekijöitä koskevan tiedon tuottamisesta. Tietoa sitten käytetään muodostamaan "affektitehdas“, eli ”organisaatio, jossa tuotanto perustuu oletukseen siitä millainen on hyvä työntekijä, miten hänen tulisi tehdä työnsä ollakseen tuottava ja miltä työn tulisi tuntua” (mt., 201). Kyse on työmoraalin tuottamisesta.

Affektitehtaan oletukset ja sen oppien sovelluskohteet saattavat muuttua, mutta Mannevuon tarkastelemien lähteiden pohjalta itse tehostamisajattelu on säilynyt yllättävän samankaltaisena yli sata vuotta. Mannevuo esittää näin kritiikkiä sellaisia historiaa abstrahoivia näkemyksiä kohtaan, joiden mukaan länsimaissa on siirrytty fordismista postfordismiin tai kuriyhteiskunnasta kontrolliyhteiskuntaan tavalla, joka muuttaa kaiken. Mannevuon mukaan siirtymiä on kyllä tapahtunut, mutta ei esimerkiksi siten, että "ennen" työ olisi ollut vailla tunteiden hallintaa. 
Tuoreessa Ihmiskone töissä (2020) -kirjassaan Mannevuo tarkastelee työn järjestämistä sekä affektiivisesta että koneellisesta näkökulmasta. Hän kysyy, kuinka työtä tehostavaa itsekuria on iskostettu suomalaisiin erityisesti sotakorvausteollisuuden aikana 1940-ja 1950-luvuilla. Teos on kirjalliseen aineistoon perustuva ja laajasti kontekstoiva tutkimus suomalaisen tehokkuusajattelun aate- ja tunnehistoriasta. Mannevuo käy läpi työnjohtokirjallisuutta, työpsykologian oppeja, johtajille suunnattuja kirjekursseja, työterveyshuollon näkemyksiä sekä näiden yhdysvaltalaisia ja saksalaisia esikuvia. Näin muodostuu kuvaus työn tehostamisesta pääoman ja valtion näkökulmasta. Se koostuu kontrollin edustajien käsityksistä ja toisaalta toivomuksista siitä, miten teollinen työ järjestetään ihannetapauksessa. Mannevuo kirjoittaa (mt., 57, 196), että hänen aineistonsa jättää avoimeksi kysymyksen siitä, miten työläiset suhtautuivat tehostamiseen ja millaista työn organisointi on todellisuudessa ollut tuotannon lattiatasolla.

Metodiltaan Ihmiskone töissä on foucault'laista nykyisyyden historiaa, genealogiaa, jonka tavoite on auttaa meitä ymmärtämään, "miksi olemme sellaisia kuin olemme” (mt., 7). Teos etsii hallinnan malleja ja teknologioita eikä yritä tehdä klassista historiankirjoitusta. Mannevuo ei kuitenkaan lähde teoreettisiin keskusteluihin hallinnan tutkimuksesta, ja muutenkin hänen otteensa eroaa Foucault'n karvalakkisovelluksista. Dramaattisten katkosten sijaan Mannevuo on kiinnostunut jatkuvuudesta, esimerkiksi siitä, miten työväestöä ohjataan ja paimennetaan vuosikymmen toisensa jälkeen tuottamalla itsekuria, jonka avulla työläisen on määrä sopeuttaa itsensä ylhäältä annettuihin tavoitteisiin. Mannevuo suorasanaisesti määrittelee "valtasuhteita jälkikäteen tarkastelevan historiantutkimuksen" tavoitteeksi "etsiä jatkumoita" (mt., 25).

Kulttuurintutkijana Mannevuo löytää työmoraalin nykyisyyteen ulottuvan jatkumon lähtökohtia erilaisten lähinnä ulkomaisten tieteellisten oppien soveltamisesta. Tätä voi verrata esimerkiksi Päivi Uljaksen (2012) hyvinvointivaltion varhaishistoriaa käsittelevään perinteisempään tutkimukseen, joka löytyy myös Mannevuon läh- deluettelosta. Uljaksen mukaan suomalainen ankaran työnteon eetos syntyi erityisesti valtion tukemasta pienviljelyksestä ja toista maailmansotaa ympäröineistä agraarisista olosuhteista. Näissä olosuhteissa ahkeruus, siisteys, vahvuus ja ripeys takasivat osalle köyhistäkin vähimmäisturvan, arvostusta maaseutuyhteisön silmissä ja jonkinlaisen omavaraisuuden. Kovalla työnteolla haettiin myös tasa-arvoa: se asetettiin vanhan sääty-yhteiskunnan syntyperäistä eriarvoisuutta vastaan. Siinä missä Mannevuo tarkastelee tiedontuotantoa, joutilaisuuden eliminoimista ja ahkeruuden korostamista teollisen palkkatyön ylhäältä annetuissa opeissa, Uljas alleviivaa, että vielä 1950-luvulla palkkatyöläisyys ei ollut Suomessa vallitseva elämänmuoto, vaan enemmistö väestöstä eli yhdistelemällä pienviljelystä, pienyrittäjyyttä ja työpätkiä.

Molemmat tutkimukset antavat sotienjälkeisestä ajasta kuvan, jonka mukaan elämällä ei Suomessa ollut useimmille aikuisille juuri muuta sisältöä kuin työ. Työ oli käytännössä ainoa sosiaaliturva, sen ajateltiin olevan parasta mielenterveyshoitoa, sillä maksettiin sotakorvaukset ja rakennettiin kansakunnan elinvoimaa. Niin kuin Mannevuo (2020, 136) kirjoittaa, "sotienjälkeisen Suomen rationalisoidussa yhteiskunta-ajattelussa kansanterveys, tuottavuus ja kilpailukyky kytkeytyvät toisiinsa”.

Sama yhdistelmä on käytössä 2020-luvulla, kun ihmiskonetta viritetään tuottavaksi konsulteilla, self helpillä, sosiaalisen median vertaispaineella ja mediapuheella. Jokaisella on henkilökohtainen velvollisuus pitää huolta työkyvystään, ja politiikan ylimpänä tavoitteena on kilpailukyvyn kohottaminen.

\section{Neurorationalisoinnin jatkumot}

Toisen maailmansodan jälkeen valtiojohtoinen sotakorvausteollisuus synnytti kysyntää työn tehostamisen opeille. Niiden kanssa kehitettiin työterveyttä ja työturvallisuutta. Pyrkimyksenä oli ratkaista kysymys työväenliikkeestä tieteellisesti siten, että ammattimaisesti koulutettu työnjohto sovittaa työläisten ja ylempien tahojen välisen antagonismin. Työstä oli sovittava objektiivisesti. 
Ammattiyhdistysliike saatiin mukaan tehostamisoppiin, kun uudistajat korostivat toimien lisäävän terveyttä ja turvallisuutta sekä lupasivat huomioida työntekijöiden erilaiset tilanteet.

Mannevuo nostaa kiinnostavasti esiin Rockefeller-säätiön toiminnan tehostamisoppien tuomisessa Pohjoismaihin. Säätiö edisti yleisesti tutkimusta, "jonka tehtävä oli parantaa kansakunnan ainesta ja rotujen välisiä suhteita" (Mannevuo 2020, 114). Se esimerkiksi tuki sosiaalipolitiikan professori Heikki Wariksen tutkimuksia karjalaisen siirtoväen sopeuttamisesta, rahoitti ruotsalaista kansankotia sekä eugeniikkaa suunnitelleita Alva ja Gunnar Myrdalia, auttoi suomalaisia modernisoimaan sairaanhoitokoulutusta, myönsi stipendejä suomalaisille lääkäreille ja avusti Suomen Työterveyslaitoksen perustamisessa.

Yhtäältä kyse oli amerikkalaisten antikommunismista. Neuvostoliiton takia Suomi ei voinut vastaanottaa Marshall-apua, mutta työväenliikkeeseen oli mahdollista vaikuttaa muuttamalla työn organisoimista koskevaa ajattelua. Toisaalta Yhdysvallat tarjosi suomalaisille mahdollisuuden ulottua kauemmas länteen ja sen edustamaan tieteelliseen kehitykseen, jota natsihallinnon tärvelemä Saksa ei enää tarjonnut. Sinänsä "uuden" tehokkuusajattelun tavoite oli sama kuin ennen sotia: ihmisen tieteellis-tekninen tehostaminen.

Ihmiskoneen Mannevuo määrittelee ruumiin ja hermoston toimintojen optimoimisen malliksi Lauri "Tahko" Pihkalan Joka miehen koneopin (1909) mukaan. Taustalla oli höyrykoneiden kehitys $1800-l u v u l l a$, sähkömagneettisten voimakenttien ajattelu sekä termodynaaminen näkemys jatkuvasta taistelusta järjestystä uhkaavaa entropiaa eli kaaosta vastaan. Koneopin aatehistoriaa voisi kaivaa syvemmältäkin, esimerkiksi $1700-l u v u n$ valistuksen yleisistä konemetaforista, Julian Offray de La Mettrien vitalistisesta Ihmiskoneesta (1747) tai Descartesin mekanistisesta ajattelusta, mutta Mannevuo rajaa tutkimuksensa suomalaiseen työajatteluun ja sen suoriin esikuviin.

Mannevuo käyttää suomalaisen hyvinvointipolitiikan tulkinnan välineenä Kyla Schullerin (2018) käsitettä biofilantropia, joka tässä yhteydessä tarkoittaa "kansakunnan vitaalisen energian optimointia 'hyvillä kehillä' eli sosiaalipo- liittisilla ratkaisuilla, jotka kohentavat työkykyä, hyvinvointia ja terveyttä” (Mannevuo 2020, 111). Biofilantropia yhdistää biovallan, hyväntekeväisyyden ja hyvinvointivaltion. Mannevuo liittää tämän Ilpo Helénin (2016) käsittelemään affirmatiiviseen biopolitiikkaan eli kansalaisten potentiaalin kultivointiin myötäilemällä ja ohjailemalla.

Kolmas tärkeä tutkimuskäsite on sosiaalinen insinööritaito eli "pragmaattinen yhteiskuntapolitiikka, jossa sosiologit, psykologit, taloustieteilijät ja insinöörit soveltavat tieteellisiä ja teknisiä löydöksiä yhteiskunnan vaurauden ja hyvinvoinnin kohentamiseksi" (Mannevuo 2020, 23). "Insinööräys" on tuottanut arvostettuja uudistuksia, kuten siistejä vuokra-asuntoja ja sosiaalipalveluja. Sen kääntöpuolena on ajatus vastikkeellisuudesta, joka sisältää käsityksen oikeasta ja väärästä tavasta elää yhteiskunnassa.

Kaikki edellä mainittu - työpsykologia, yhteiskunnan insinöörityö, biopolitiikka ja biofilantropia sekä ihmisruumiin koneellinen optimointi yhdistyy neurorationalisoinnin käsitteessä, jolla Mannevuo (mt., 26) viittaa "hermojen ja tunnetilojen tarkkailuun, kontrolliin ja hallintaan". Se tarkoittaa, että työnjohto ei voi rajoittua vain työpaikalle vaan sen on oltava kokonaisvaltaista elämän halllintaa. Neurorationalisointi on nähdäkseni kirjan tärkein käsitteellinen luomus, hieno keksintö, joka tuntuu käyttökelpoiselta, kun tarkastellaan nykyisiä työn (ja elämän!) järjestämisen oppeja. Käsite kytkee Mannevuon käsittelemät tehokkuusajattelun muodot jatkumoksi.

Esimerkki Mannevuon löytämästä jatkumosta: Niin kuin 1940-luvulla, myös 2020-luvulla työntekijöille jaetaan jatkuvasti ohjeita siitä, miten elämää tulisi elää oikein. Ohjeita yhdistää pelko ihmisten laiskuudesta ja tuottamattomuudesta. Suomessa työntekijöiden mahdollisesta toimettomuudesta oltiin sotien jälkeen aivan erityisen huolissaan, sillä oletus oli, että suomalaiselle työläiselle joutilaisuus on kärsimystä ja johtaa huonoihin houkutuksiin. Niin silloin kuin nytkin yksilön lorvailu ei ole hänen oma asiansa vaan valtiollinen ongelma, johon on puututtava erilaisilla aktivointitoimilla, "jatkuvalla huolenpidolla, valvonnalla ja patistelulla“(Mannevuo 2020, 165).

Myös hyvän työntekijän ihanteissa on jatku- 
vuuksia. Kunnon työihminen on edelleen elinvoimainen, tasapainoinen ja liikunnallinen kone. Vuonna 1915 julkaistussa Työn tieteessä geologi J. J. Sederholm katsoi, että menestyjän erottaa epäonnistujasta kyky hallita omaa elämää ja aikaa; näkemys on erittäin 2020-lukulainen. Heikkouksiakin jaotellaan joiltain osin samoin kuin 70 vuotta sitten. Työntekijän on esimerkiksi parempi olla työuupunut kuin laiska, sillä uupunut sentään yrittää olla aktiivinen ja hänen uupumuksensa on merkki pyrkimyksestä ahkeruuteen, toisin kuin laiskan toimettomuus.

Jatkumoa on työn ja sen tekijän jatkuva mittaaminenkin. Tayloristisiin työoppeihin on aina kuulunut intensiivinen mittaaminen, ja nyt työntekijät voivat - heidän kannattaa, ehkä jopa täytyy - myös itse mitata itseään sovelluksilla ja älykelloilla. Mittarit auttavat loppumattomassa taistelussa epäjärjestystä ja tuhlailua vastaan. Viime vuosisadan puolivälissä tähän liittyi hygieniaa korostava ajattelu, nykyään taas ihanne minimalistisesta estetiikasta ja "aivoergonomia".

Vielä yksi esimerkki työn tehostamisen jatkumosta on neuroplastisuuden käsite. Viime vuosikymmeninä aivojen joustavuudesta ja muovailtavuudesta on tullut teema, joka on noussut aivotutkimuksen ohella näkyvästi esimerkiksi bisnes- ja itsehoitokirjallisuudessa sekä filosofiassa. Teoria plastisista aivoista keksittiin kuitenkin jo 1800-luvun lopulla, ja Mannevuo $(2020,38) \mathrm{ku}-$ vailee, kuinka "sotienjälkeiset työnjohto-opit läpäisee ajatus työväestön muovautuvuudesta ja plastisuudesta - ja toisinaan sen puutteesta”. Itse voisin ulottaa aatehistoriallisen kaivamisen vaikka Platoniin, jonka mukaan ideat tuodaan ulkoa käsin plastisiin sieluihin.

Modernin neurorationalisoinnin historiassa näkemys aivojen plastisuudesta on johtanut kouluttamaan työntekijöistä itsekurillisia sopeutujia. Pitkäikäinen näkemys suomalaisesta "jäykästä ja epäplastisesta sielusta" taas ilmenee nykyään Mannevuon (mt., 164-165) mukaan esimerkiksi "sisututkija" Emilia Lahden tutkimuksissa. Niissä sisusta tulee yhteisölle arvokas psykologinen tahtotila, kunhan se yhdistyy muiden sisujen kanssa tuottamaan vitaalista energiaa.

\section{Tiedepohjaisen politiikan ongelmia}

Hienoa Ihmiskone töissä -kirjassa on tapa, jolla Mannevuo käsittelee neurotieteiden uutta ja vanhaa käyttöä. Aivotutkimuksen soveltaminen politiikkaan ja yhteiskuntasuunnitteluun on lisääntynyt erityisesti vuoden 2008 talouskriisin jälkeen. Silloin syntyi neurotaloustiede, jossa yhdistyivät taloustiede, sosiaalipsykologia ja popularisoitu aivotiede. Neurotaloustieteessä on keksitty muun muassa näkemys, jonka mukaan talouskriisi oli myös neurokriisi, sillä Yhdysvaltojen asuntokupla johtui ahneudesta ja itsekurin puutteesta. Neurotieteiden pohjalta on katsottu myös, että koska ihmiset ovat lähempänä Homer Simpsonia kuin rationaalista toimijaa, kansalaisia on holhottava "tuuppauspolitiikalla" (nudge, Thaler \& Sunstein 2008) ja erilaisilla neuroliberalistisilla mekanismeilla. Näihin kuuluvat valinta-arkkitehtuurien ja "hyvän kehien" suunnittelu, ajatushautomoiden toiminta, pehmeä paimenvalta ja jatkuva yhteiskuntapoliittinen kokeilukulttuuri.

Jos noin 40 vuotta sitten elettiin sosiaalisen konstruktionismin aikaa, nyt hallinnan perusteluissa on palattu biologisointiin ja perimän korostamiseen tavalla, joka muistuttaa 1800-luvun loppua. Perusteita erilaisille aktivointitoimille ja holhousmekanismeille löydetään neurotieteistä, kognition tutkimuksesta ja jopa suoraan aivokuvista. Uudet löydökset tavataan esittää mullistuksellisina, vaikka esimerkiksi talousnobelisti Daniel Kahnemannin (2011) ajatus kahdesta ajattelun systeemistä, intuitiivisesta ja rationaalisesta, on Mannevuon mukaan tuttu jo suomalaisista 1940-luvun työnjohto-opeista. Molempien taustalla on myös kytkös armeijan oppeihin: suomalaisella työnjohdolla toisen maailmansodan kokemukset ja rintamamiesten sopeuttaminen tehdaskuriin, Kahnemannilla työskentely Israelin armeijalle.

Mannevuo kysyykin, tarjoaako nykyinen neurorationalisointi uudessa paketissa saman, mitä Teollisuuden työnjohto-opiston vararehtori Erkki Mielonen tarjosi Luonneoppi-kirjekurssillaan 1948. Mielosen mukaan ihminen on koneisto, jonka älyllisten toimintojen tulee oppia hallitse- 
maan tunne- ja vaistotoimintoja. Työläisten on otettava aivojen epärationaaliset voimat hallintaan itsekurilla. Näkemys on historiallisesti liukunut herkästi suuntiin, joissa yksilöitä on jaettu rationaalisiin menestyjiin ja irrationaalisiin valittajiin, miehiin ja naisiin, sivistyskansoihin ja luonnonkansoihin. (Yksi muotoilu tästäkin neuropopulismista on esitetty jo Platonin Valtiossa.)

Mannevuo näkee aivopopularistisissa opeissa kulttuurintutkija Melissa Greggiä (2018) mukaillen kristillisen kaavan: kansalaisen on tunnistettava itsensä syntiseksi tuottamattomuudessaan. Paraneminen alkaa seuraamalla asiantuntijoiden oppeja. Niiden avulla jokainen voi tulla paremmaksi versioksi itsestään.

Neurorationalisoinnin kriittinen tutkimus herättää kysymyksen siitä, mitä on tiedepohjainen päätöksenteko, johon jatkuvasti vedotaan ja jota toivotaan politiikan perustaksi. Hyvinvointivaltion alkuaikoina tiedepohjaisuus johti Suomen vuosien 1935 ja 1953 sterilointilakeihin, joilla rajoitettiin "heikomman aineksen" lisääntymistä. Pakkosterilointeja ja ihmisten sulkemista laitoksiin on nykynäkökulmasta helppo pitää epätieteellisinä ääriesimerkkeinä. Samaan aikaan julkisessa keskustelussa otetaan kuitenkin vakavasti aivotutkijoiden rottakokeista tekemiä päätelmiä siitä, miten ihmisten tulisi johtaa omaa elämäänsä, ja käytetään psykologiaa ja neurotieteitä siihen, että vastuuta siirretään yksilölle kollektiivisen politiikan sijaan.

\section{Katkoksia ja uupumusta}

Ihmiskone töissä tarkastelee jatkumoiden lisäksi joitakin katkoksia sodanjälkeisen teollisuustyön ja nykyisen muodottomaksi levinneen työn välillä. Ensimmäinen katkos on jo alussa mainittu tunteiden ilmaisemisen tapa. 1900-luvun puolivälissä ihanteellinen työntekijä sopeutui hierarkkiseen työyhteisöön piilottamalla henkilökohtaiset tunteensa. Nyt ainakin myönteisten tunteiden ilmaisemista pidetään hyveenä, ja työntekijöitä rohkaistaan löytämään aito, luova ja henkilökohtainen intohimo. Sellaisella ei olisi tehnyt kovin paljon sotakorvaustehtaassa.
Toinen katkos on 1980-luvulla Yhdysvalloista kantautunut ihanne huippuyksilöstä ja jatkuvasta itsensä ylittämisestä. Kun teollisessa työssä tavoitteena oli tasainen normisuoritus, sääntely koski alisuorittajien lisäksi ylisuorittajia. Liika intoilu ja säntäily häiritsi rationaalisesti suunniteltua tuotantoa. Nykyään taas ihanteena on nimenomaan ylisuorittaminen, jatkuva riskinottaminen ja "virallisesti" vaaditun tason ylittäminen.

Kolmas katkos on taso, jolla työnjohto-opeissa ja politiikassa etsitään ratkaisuja rakenteellisiin ongelmiin. Nykyään tuottavuuden, hoivan ja mielenterveyden kysymyksiä pyritään ratkomaan yksilöllisesti, esimerkiksi itseapukirjallisuudella, terapialla ja vastuullistamisella. Sotienjälkeisessä yhteiskuntasuunnittelussa ote oli kollektiivisempi ja jopa utopistinen, kun rakennettiin päiväkoteja ja sosiaaliturvaa.

Olisiko katkoksista kaivettavissa vastarinnan muotoja nykyiselle neurorationalisoinnille? Affektitehtaan lopussa Mannevuo näki fordistisessa "organisaatioihmisessä" mahdollisuuksia vastarintaan. Organisaatioihminen "antaa itsestään töissä vain sen verran kuin on välttämätöntä”, "esittää innostunutta vain sen verran kuin on pakko", ei etsi syvempää merkitystä nykytyön sosiaalisista eleistä, kyseenalaistaa affektiivisen rationalisoinnin, ei luota työn tieteisiin vaan etsii omaa etuaan ja ennen kaikkea tietää, että kaikesta tunneja neuroretoriikasta huolimatta affektitehtaan ja työläisen välillä on aina konflikti (Mannevuo 2015, 210).

Ihmiskone töissä -kirjassa vastarintaa voi etsiä "väsyneiden, uupuneiden, ylivireisten, haluttomien ja jurottajien" "arvoituksellisesta ryhmästä", jota ei ole voinut vapauttaa työstä ja jota ei toisaalta pitää hyvänä työvoimana (Mannevuo 2020, 18-19). Uupumus, riitely, epätoivo tai luovuttaminen eivät kuulu suomalaiseen tehokkuusajatteluun eivätkä kansalliseen historiankäsitykseen. Siksi "vaikuttaa siltä, että turhiksi, kelvottomiksi tai tuottamattomiksi nimetyillä ei ole historiaa, ellei sitä osaa etsiä vaikka psykopatian tai työlaitosten historiasta tai hyvinvointivaltion alaviitteistä" (mt., 285).

Ihmiskoneen historian jälkeen olisi herkullista lukea suomalaisen työstäkieltäytymisen tai lais- 
kottelun historiaa, tai miksei nautiskelun historiaa. Luennollaan itsekurin nykyisyyden historiasta Mannevuo (4.11.2020) huomautti, että meillä on hyvin vähän tarinoita siitä, miten joku tekee asioita huvikseen, ihan vain ajankuluksi.

\section{KIRJALLISUUS}

Gregg, Melissa (2018) Counterproductive. Time Management in the Knowledge Economy. Durham, Duke University Press.

Helén, Ilpo (2016) Elämän politiikat. Yhteiskuntatutkimus Foucault'n jälkeen. Helsinki, Tutkijaliitto.

Kahneman, Daniel (2011) Thinking, Fast and Slow. New York, Farrar, Straus and Giroux.

Mannevuo, Mona (2015) Affektitehdas. Työn rationalisoinnin historiallisia jatkumoita. Turku, Turun yliopisto.

Mannevuo, Mona (2020) Ihmiskone töissä. Sotienjälkeinen Suomi tehokkuutta tavoittelemassa. Helsinki, Gaudeamus.

Schuller, Kyla (2018) The Biopolitics of Feeling. Race, Sex and Science in the Nineteenth Century. Durham, Duke University Press.

Thaler, Richard H. \& Cass R. Sunstein (2008) Nudge: Improving Decisions about Health, Wealth, and Happiness. New Haven, Yale University Press.

Uljas, Päivi (2012) Hyvinvointivaltion läpimurto. Helsinki, Into. 